\title{
Are VLEs still worthwhile?
}

\section{Christine Davies}

University of Wales Trinity Saint David.

\section{Abstract}

This opinion piece considers the current value of Virtual Learning Environments (VLEs), and associated technologies such as e-portfolios, from the perspective of both lecturers and learners. Student satisfaction is discussed, and the relationship between VLE engagement and academic performance is considered. The piece concludes by highlighting the need for flexibility in the ways in which universities utilise technologies for teaching and learning.

Keywords: Virtual Learning Environments; VLE; VLE engagement; institutional technology; NGDLE.

\section{Introduction}

'Virtual Learning Environments' (VLEs), or 'Learning Management Systems' (LMS) started to appear in Higher Education Institutions (HEls) in the late 1990s. Their uptake was rapid, accelerated by national and international policy (Konrad, 2003) and initiatives such as the Open University's (OU) VLE project (Weller, 2006). By 2007, VLEs had become ubiquitous, and currently include 'Blackboard', 'Moodle', and 'Canvas'.

Back in 2006, Martin Weller from the OU believed that VLEs acted as pioneers, paving the way for many more exciting technological developments in teaching, learning and assessment (Weller, 2006). However, other authors were anxious that VLEs were too traditional in approach, primarily acting as administrative tools (Blin and Munro, 2008), and even having the effect of inhibiting innovation in HEl technology (Stiles, 2007). There was a recognition that online learning, including VLEs, required sound design (Laurillard, 
2010), and substantial interactivity (Salmon, 2002). It was also realised that in addition to IT specialists, tutors and librarians had a key role to play in setting up and promoting VLE pages (Markland, 2003). Tutors also needed support and training to help them use VLEs effectively (Comas-Quinn 2012), and this was also the case for technologies that sit within VLEs, such as e-portfolios (e.g. Pebblepad), assignment submission and plagiarism detection software (e.g. Turnitin), and lecture-capture technology (e.g. Panopto).

HEls continue to invest a great deal of money and time in VLEs and associated technologies, in the hope that they will help them be competitive (Stoller, 2016), and with the implicit assumption they improve teaching and learning. However, assumptions about the pedagogic value of educational technologies are not always correct. Interactive whiteboards, for example, were installed in large numbers in school classrooms across the UK and elsewhere over the last twenty years but are now generally used as if they were merely ordinary (and substantially cheaper) whiteboards (Schnackenberg and Vega, 2016).

Is there a good enough return on investment in the case of university VLEs? Do they help lecturers to teach their subjects and courses? Do they enrich students' learning experience and lead to higher marks?

\section{VLEs and lecturers}

There is little in the literature that examines whether VLEs have directly benefitted university teaching, though Hew and Syed Abdul Kadir working in Malaysia linked 'instructor effectiveness' with factors such as trust in the technology and support from the institution (Hew and Syed Abdul Kadir, 2016). Chris Shelton surveyed academic staff from 27 English universities to gauge their views on VLEs and other institutional technologies (Shelton, 2014). He found that around $60 \%$ of respondents used their institutional VLE frequently, but there was considerable variation across HEls in lecturers' levels of confidence in their use. Some of the lecturers responding to the survey commented that they continued to use institutional technologies such as VLEs even though they 'did not consider them to have a positive effect on learning' (Shelton, 2014, p.757), and Shelton 
speculated that for some lecturers 'institutional rules or expectations require them to use technology in ways with which they are not comfortable' (Shelton, 2014, p.757). He also noted that barriers to lecturer engagement with institutional technologies such as VLEs included lack of training, and lack of support, but the major barrier, mentioned by $65 \%$ of his respondents, was lack of time. This was also found to be the case by other authors such as Farrelly et al (2018).

\section{VLEs and learners}

Student satisfaction with VLEs appears to vary by institution (Shelton, 2014) and course (Boulton et al, 2018), though it is not uncommon to have a low frequency of interaction with VLE resources (Agudo-Peregrina et al, 2014; Davies and Harries, 2016), or for students to spend little time engaging with VLE resources (Boulton et al, 2018). Surveys of students have indicated that student satisfaction, and also student retention, increase with the richness of VLE communication tasks (Rienties and Toetenel, 2016), and this reinforces the early work in this area by authors such as Salmon (2002). Distance learners in particular seem to appreciate VLE activities which are social and tutor-led (AgudoPeregrina et al, 2014; Tour, 2017).

Does the engagement of students with VLEs improve their academic performance? To provide a sound answer to this question we need robust measures of student engagement. Many studies in this area have used survey responses for this purpose (e.g. Toole et al, 2015), but surveys may provide unrepresentative samples, and it is also possible for students to over-estimate their VLE usage. It could be argued that a 'learning analytics' approach is a superior way of gauging VLE engagement (Agudo-Peregrina et al, 2014; Boulton et al, 2018). This approach can involve counting the number of clicks on a webpage (e.g. Agudo-Peregrina et al, 2014; Rienties and Toetenel, 2016), the number of contributions a student makes, for example on a VLE forum (e.g. Goggins and Xing, 2016), or the time spent on a web-page (e.g. Boulton et al, 2018). Boulton et al (2018) examined the VLE engagement and ultimate achievement of campus-based undergraduates on a range of courses. They found a positive association between VLE 
usage and class of degree in some subjects (e.g. medicine), but not in others (e.g. mathematics). Agudo-Peregrina et al (2014) found a significant positive association between VLE engagement and performance for online courses, but not for 'blended' courses where there was some face-to-face delivery in addition to VLE based study. This was also observed by Davies and Harris (2016).

E-portfolios play an important role within VLE usage on several HE courses, particularly those with practice-based components such as nursing. Though not widespread in some countries, for example Ireland (Farrell, 2018), they have been used extensively in regions such as the United States (Kahn et al, 2014; Association of American Colleges and Universities, 2020). However, Kahn et al (2014) noted that within any one US institution usage of e-portfolios was sparse. This ties in with Shelton's (2014) survey of English HEls which found that less than $10 \%$ of tutors used e-portfolios frequently. Technical difficulties appeared to be a barrier to e-portfolio uptake in the case of both academic staff (Andrews and Cole, 2015) and students (Birks et al, 2016). However, many studies, for example, Roberts et al (2016), have commented that eportfolios help to promote reflective thinking.

Turnitin is another application used widely in conjunction with VLEs. Primarily designed to detect plagiarism, this technology can help students learn about aspects of academic writing (Abrahamson \& Mann, 2018). Turnitin also acts as a key portal for uploading and assessing assignments, and a means of providing feedback to learners. On some HE courses, the requirement to submit assignments via Turnitin, or an equivalent VLE component, may be the prime motivator in students' engagement with their institutional VLE (Hampel \& Pleines, 2013).

VLEs may also incorporate lecture capture. A review of the literature on this topic by O'Callaghan et al (2017) suggested that the benefits of this technology outweigh its drawbacks, and Dommett et al (2019) noted that lecture capture may be particularly beneficial for learners with health issues who may have to miss lectures. However, Ikonne et al (2018) noted that the availability of lecture capture on a medical course was associated with a reduction in attendance at lectures, and Edwards and Clinton (2018) also found a negative association between lecture capture and attendance on a UK 
undergraduate science module. Both of these studies found that viewing videos of lectures did not appear to improve student achievement. Edwards and Clinton (2018) held the view that the 'net effect of lecture capture introduction... is generally negative' (Edwards and Clinton, 2018, p.403).

\section{Looking to the future}

The evidence of the value of VLEs and associated technologies is clearly mixed and, in many cases, HEls may be continuing to use them because of past investment rather than their benefits to teaching and learning. Dron and Anderson (2016, p.11) made reference to 'the monolithic LMS', and Salmon and Asgari (2019, p.1) similarly commented that when it comes to institutional technology there is 'stasis in the university sector'. With the increasing range and accessibility of information online, students may not need typical VLE content and may decide to use their VLE purely to access Turnitin or equivalent for assignment submission. The increasing numbers of learners who are part-time, mainly distance-based and/or professionally focussed may preferentially use online resources which are visually appealing, do not require login, and are easily accessible on mobile devices. The increased time spent online during the 2020 COVID-19 pandemic may have further raised expectations.

The 2020 Educause Horizon report on Teaching and Learning lists 'Next Generation Digital Learning Environments' (NGDLE) as one of the key current technological trends in the HE sector (Educause, 2020). These environments are considered to be 'learning ecosystems' that incorporate some existing features of a VLE, but additionally use learning analytics to give increased flexibility and agility. They may constitute a major improvement on VLEs because of the provision of a more personalised learning experience that includes synchronous and asynchronous elements, advice, collaboration and assessment (Educause, 2015).

The flexibility promised by NGDLE is vital and links to the observations of Orr et al (2018, p.12) who commented that 'there is no 'one size fits all' approach to the implementation of technology'. This translates into a need for a range of technological 
options and the freedom to choose the tools that best suit specific learners and courses. It also necessitates adequate time and support for lecturers so that they can maintain awareness and understanding of the increasing range of online delivery options.

\section{References}

Abrahamson, E. and Mann, J. (2018) 'For whom is the feedback intended? A studentfocused critical analysis of Turnitin software as a tool for learning'. Journal of Pedagogical Research, 2(3), pp. 146-166.

Agudo-Peregrina, A.F., Iglesias-Pradas, S., Conde-González, M.A., and HernándezGarcía, A. (2014) 'Can we predict success from log data in VLEs? Classification of interactions for learning analytics and their relation with performance in VLEsupported F2F and online learning'. Computers in Human Behaviour, 31, pp. 542550.

Andrews, T. and Cole, C. (2015) 'Two steps forward, one step back: The intricacies of engaging with eportfolios in nursing undergraduate education'. Nurse Education Today, 35(4), pp. 568-572.

Association of American Colleges and Universities (2020) 'ePortfolios' [online] Available at: https://www.aacu.org/eportfolios [Accessed 10.7.20].

Birks, M., Hartin, P., Woods, C., Emmanuel, E. and Hitchins, M. (2016) 'Students' perceptions of the use of e-portfolios in nursing and midwifery education'. Nurse Education in Practice, 18, pp. 46-51.

Blin F., Munro, M. (2008) 'Why hasn't technology disrupted academics' teaching practices? Understanding resistance to change through the lens of activity theory.' Computers \& Education Volume 50 (2), pp. 475-490. 
Boulton, C.A., Kent, C. and Williams, H.T.P. (2018) 'Virtual learning environment engagement and learning outcomes at a 'bricks-and-mortar' university'. Computers \& Education 126, pp. 129-142.

Comas-Quinn, A., de los Arcos, B. and Mardomingo, R. (2012) 'Virtual learning environments (VLEs) for distance language learning: shifting tutor roles in a contested space for interaction.' Computer Assisted Language Learning, 25(2), pp. 129-143.

Davies, C. and Harries, L. (2016) 'Engagement of professional learners with the VLE: a case study from social care'. Wales Journal of Learning and Teaching in Higher Education, 1 (1), 60-65 pp. [online] Available at:

https://www.uwtsd.ac.uk/media/uwtsd-website/contentassets/documents/enhancement-unit/wales-journal/60-65-Davies-and-Harris.pdf (Accessed 4.4.20)

Dommett, E.J., Gardner, B. and van Tilburg, W. (2019) 'Staff and student views of lecture capture: a qualitative study'. International Journal of Educational Technology in Higher Education, 16 [online]. Available at: https://educationaltechnologyjournal.springeropen.com/articles/10.1186/s41239019-0153-2 [Accessed 22.3.20].

Dron, J. and Anderson, T. (2016) 'The Future of E-learning', pp.1-23, in Haythornthwaite, C., Andrews, R., Fransman, J. and Meyers, E.M. (eds). SAGE Handbook of Elearning Research, $2^{\text {nd }}$ edn. London: Sage.

Educause (2015) ' 7 things you should know about NGDLE'. Educause Learning Initiative [online]. Available at: https://library.educause.edu//media/files/library/2015/12/eli7127-pdf.pdf [Accessed 10.7.20].

Educause (2020) 2020 Educause Horizon Report, Teaching and Learning Edition. [online] Available at: https://library.educause.edu/- 
/media/files/library/2020/3/2020_horizon_report_pdf.pdf?la=en\&hash=08A92C1799 8E8113BCB15DCA7BA1F467F303BA80 [Accessed 10.7.20].

Edwards, M.R. and Clinton, M.E. (2019) 'A study exploring the impact of lecture capture availability and lecture capture usage on student attendance and attainment', Higher Education, 77(3), pp. 403-421.

Farrell, O. (2018) 'Failure to Launch: The Unfulfilled Promise of E-portfolios in Irish higher education: An Opinion Piece.' DBS Business Review, 2, pp. 154-163.

Farrelly, T., Raftery, D. and Harding, N. (2018) 'Exploring lecturer engagement with the VLE: findings from a multi college staff survey.' Irish Journal of Technology Enhanced Learning, 3(2), pp. 11-23.

Goggins, S. and Xing, W. (2016) 'Building models explaining student participation behaviour in asynchronous online discussion'. Computers and Education, 94, pp. 241-251.

Hampel, R. and Pleines, C. (2013) 'Fostering student interaction and engagement in a virtual learning environment: An investigation into activity design and implementation'. CALICO Journal, 30(3), pp. 342.

Hew, T. and Syed Abdul Kadir, S. (2016), 'Predicting instructional effectiveness of cloudbased virtual learning environment'. Industrial Management \& Data Systems, 116 (8), pp. 1557-1584.

Ikonne, U., Campbell, A.M., Whelihan, K.E., Bay, R.C. and Lewis, J.H. (2018) 'Exodus From the Classroom: Student Perceptions, Lecture Capture Technology, and the Inception of On-Demand Preclinical Medical Education'. The Journal of the American Osteopathic Association, 118(12), pp. 813-823.

Kahn, S. (2014) 'E-portfolios: a look at where we've been, where we are now, and where 
we're going.' Peer Review Washington, 16(1), pp. 1-5.

Konrad, J. (2003) 'Review of educational research on virtual learning environments [VLE] implications for the improvement of teaching and learning and access to formal learning in Europe.' Proc European Conference on Educational Research, University of Hamburg, 17-20 September 2003 [online]. Available at: http://www.leeds.ac.uk/educol/documents/00003192.htm [Accessed 20.3.20]

Laurillard, D. (2010) 'Effective use of technology in teaching and learning in higher education', pp. 419-426, in Baker, E., Peterson, P. and McGaw, B. (eds.), International Encyclopedia of Education 4, Oxford: Elsevier.

Markland, M. (2003) 'Embedding online information resources in Virtual Learning Environments: some implications for lecturers and librarians of the move towards delivering teaching in the online environment'. Information Research, 8(4) [online]. Available at: http://informationr.net/ir/8-4/paper158\#wyn01 [Accessed 20.3.20].

O'Callaghan, F.V., Neumann, D.L., Jones, L. and Creed, P.A. (2017) 'The use of lecture recordings in higher education: A review of institutional, student, and lecturer issues.' Education and Information Technologies, 22, pp. 399-415.

Orr, D., Weller, M. and Farrow, R. (2018) Models for online, open, flexible and technology enhanced higher education across the globe - a comparative analysis. International Council for Distance Education [online]. Available at: http://oro.open.ac.uk/55299/ [Accessed 19.3.20].

Rienties, B. and Toetenel, L. (2016) 'The Impact of Learning Design on Student Behaviour, Satisfaction and Performance: A Cross-institutional Comparison across 151 Modules.' Computers in Human Behavior, 60, pp 333-41.

Roberts, P., Maor, D. and Herrington, J. (2016) 'ePortfolio-Based Learning Environments.' Journal of Educational Technology and Society, 19(4), pp. 22-33. 
Salmon, G. (2002) E-Tivities: The Key to Active Online Learning. London: Routledge.

Salmon, G. and Asgari, T. (2019) 'Higher Education - the Last Bastion? Distance and eLearning Policy and Development - The Role of e-Learning and Distance Education in the Modernisation Process of Economies, Societies and Education Systems.' European Journal of Open, Distance and E-learning, 22(1) [online]. Available at : https://www.eurodl.org/?p=current\&sp=brief\&article=792 [Accessed 18.3.20].

Schnackenberg, H.L. and Vega, E.S. (2016) 'Throwback Technologies: Interactive Whiteboards in Schools', in Schnackenberg, H.L. and Burnell, B. (eds.) Best Practices for Education Professionals, Volume Two. New York: Apple Academic Press.

Shelton, C. (2014). "'Virtually mandatory": A survey of how discipline and institutional commitment shape university lecturers' perceptions of technology'. British Journal of Educational Technology, 45(4), pp. 748-759.

Stiles, M. (2007) 'Death of the VLE?: a challenge to a new orthodoxy.' Serials, 20(1), pp.31-36 [online] available at: https://serials.uksg.org/articles/abstract/10.1629/20031/ [Accessed 10.8.20].

Stoller, E. (2016) 'The Future of UK Higher Education: why the student experience matters more than ever'. Inside Higher Ed [online] available at: https://www.insidehighered.com/blogs/student-affairs-and-technology/future-ukhigher-education [Accessed 10.7.20].

Toole, T., Khetaguri, T. and Zangaladze, M. (2015) 'An Evaluation of e-Learning in Eastern and Western Europe'. Journal of Educational Innovation, Partnership and Change, 1 (1) [online] Available at: https://www.journals.studentengagement.org.uk/index.php/studentchangeagents/art icle/view/150 [Accessed 25.9.20]. 
Tour, E. (2017) 'Teachers' personal learning networks (PLNs): exploring the nature of selfinitiated professional learning online.' Literacy, 51(1), pp. 11-18.

Weller, M. (2006) 'VLE 2.0 and future directions in learning environments'. Proceedings of The First International LAMS Conference 2006: Designing the Future of Learning [online] Available at: http://lams2006.lamsfoundation.org/pdfs/Weller_Lams06.pdf [Accessed 6.3.20].

\section{Author biography}

Dr Christine Davies is a Senior Lecturer at the Wales Academy for Professional Practice and Applied Research at UWTSD, and Programme Director for the Doctorate in Professional Practice programme. In the past, she has held professional roles in secondary schools, further education and other universities, and has significant experience of teacher training and staff development. Her early career involved biomedical research, and her $\mathrm{PhD}$ degree is in the field of respiratory physiology. Current research interests include technology in learning and teaching, and best practice in doctoral teaching and supervision. 